\title{
Pengaruh Proses Blending dan Ultrasonikasi terhadap Struktur Morfologi Ekstrak Serat Limbah Batang Kelapa Sawit untuk Bahan Baku Bioplastik (Selulosa Asetat)
}

\author{
Lestari Hetalesi Saputri ${ }^{1)}$, Romi Sukmawan ${ }^{2)}$ \\ 1,2) Politeknik LPP Yogyakarta \\ 1) lestari_h@politeknik-Ipp.ac.id, ${ }^{2)}$ romi_s@politeknik-Ipp.ac.id
}

\begin{abstract}
Abstrak
Batang kelapa sawit (BKS) hasil dari kegiatan replanting merupakan limbah bagi lingkungan apabila dibiarkan begitu saja di areal perkebunan. Padahal limbah ini mengandung selulosa cukup tinggi yang senyawa turunannya dapat diolah lebih lanjut, salah satunya menjadi bahan baku bioplastik yaitu selulosa asetat. Selulosa dapat diisolasi melalui tahapan proses chemis (ekstraksi) dan mekanis (misalnya blending dan ultrasonikasi). Penelitian ini bertujuan untuk mengetahui pengaruh masing-masing tahapan proses tersebut, terutama proses blending dan ultrasonikasi terhadap perubahan sifat morfologi serat limbah BKS. Proses ekstraksi menggunakan $\mathrm{NaOH}$ dan $\mathrm{H}_{2} \mathrm{O}_{2} 5 \%$, proses blending menggunakan PHILIPS HR2096 kecepatan 21.000 rpm dan proses sonikasi menggunakan ultrasonic cell crusher. Hasil analisa FTIR setelah proses ekstraksi menunjukkan bahwa terdapat adanya ikatan $\mathrm{O}-\mathrm{H}, \mathrm{C}-\mathrm{H}$ dan $\mathrm{C}-\mathrm{O}$ pada puncak gelombang 3410,15; 2908,65 dan 1033,85 $\mathrm{cm}^{-1}$ yang merupakan ikatan penyusun gugus utama senyawa selulosa. Hasil XRD memperlihatkan terjadi penurunan derajat kristalin sebelum dan setelah proses blending yaitu sebesar 18,26\%. Namun setelah proses ultrasonikasi terjadi kenaikan kembali nilai derajat kristalin dari 21,09\% menjadi 30\%. Karakterisasi morfologi menunjukkan bahwa proses blending dapat memisahkan struktur amorf dari serat selulosa dan proses ultrasonikasi dapat memecah serat selulosa menjadi lebih kecil. Dari penelitian ini dapat disimpulkan bahwa proses blending dan ultrasonikasi mempengaruhi perubahan struktur dan morfologi serat selulosa hasil ekstrak limbah BKS, namun penelitian ini masih perlu dikembangkan untuk mengetahui kondisi proses yang tepat untuk menghasilkan serat nanoselulosa yang lebih banyak. Kondisi proses tersebut terutama yang berkaitan dengan kecepatan putar dan waktu tinggal selama proses.
\end{abstract}

DOI: https://doi.org/10.21107/rekayasa.v13i1.6180

Kata Kunci: Derajat kristalin, Ekstraksi, Nanoselulosa, Selulosa.

\section{PENDAHULUAN}

Kelapa sawit menjadi komoditi perkebunan terbesar di Indonesia yaitu sebagai penghasil devisa utama negara disamping komoditas minyak dan gas. Berdasarkan data dari Badan Pusat Statistik (BPS), lahan perkebunan kelapa sawit Indonesia pada tahun 2010 tercatat 8,38 juta Ha dan bahkan pada tahun 2017 luasnya diperkirakan sekitar 12,31 juta $\mathrm{Ha}$ (Direktorat Jenderal Perkebunan, 2017). Namun, Asmar Arsjad (2017) menyatakan ada sekitar 1,5 juta Ha dari berjuta-juta Ha lahan perkebunan kelapa sawit milik petani yang mendesak harus segera dilakukan peremajaan (replanting). Hal ini karena usia kelapa sawit yang sudah banyak berusia lebih dari 25 tahun, bibit yang digunakan bukanlah bibit unggul dan budidaya tanaman yang kurang baik sehingga hasil panen tidak optimal. Dengan kegiatan replanting diharapkan agar kualitas dan produktivitas minyak kelapa sawit menjadi lebih baik. Akan tetapi, kegiatan replanting juga membawa dampak negatif bagi lingkungan akibat banyaknya keberadaan Batang Kelapa Sawit

\section{Article History:}

Received: September, $1^{\text {st }} 2019 ;$ Accepted: January, $12^{\text {nd }} 2020$ ISSN: 2502-5325 (Online) Terakreditasi Peringkat 3 oleh Kementerian Riset, Teknologi dan Pendidikan Tinggi (ARJUNA), berdasarkan Keputusan Direktur Jenderal Penguatan Riset dan Pengembangan No: 23/E/KPT/2019 tanggal 8 Agustus 2019
(BKS) hasil tebangan yang sangat mengganggu pengelolaan kebun bila dibiarkan begitu saja di areal perkebunan. Limbah BKS ini biasanya dibiarkan begitu saja sampai membusuk, sehingga menjadi sarang bagi kumbang Oryctes rhinocerus (Moore, 2013) yang dapat menjadi ancaman bagi tanaman sawit muda. Padahal, BKS tua sebagaimana batang kayu berserat lainnya juga memiliki kandungan selulosa tinggi yang berpotensi untuk dimanfaatkan di bidang industri, baik dalam bentuk murninya maupun turunan senyawanya (derivat selulosa). Salah satu produk turunan selulosa yang banyak digunakan di industri yaitu selulosa asetat. Produk turunan ini kebanyakan digunakan untuk tekstil, filter rokok, plastik, film fotografi, pelapis kertas, membran dan kemasan (Gemili et al, 2010; Robertson et al, 2012).

Dalam upaya mendapatkan selulosa murni dengan kandungan $\alpha$-selulosa tinggi dan cocok untuk aplikasi bioplastik, maka diperlukan beberapa treatment isolasi baik secara kimia (ekstraksi) maupun mekanis. Treatment ektraksi serat selu-

\section{Cite this as:}

Saputri, L.H. Sukmawan, R. (2020). Pengaruh Proses Blending dan Ultrasonikasi terhadap Struktur Morfologi Ekstrak Serat Limbah Batang Kelapa Sawit untuk Bahan Baku Bioplastik (Selulosa Asetat). Rekayasa, 13(1), 15-21. doi: https://doi. org/10.21107/rekayasa.v13i1.6180 
losa meliputi tahapan delignifikasi dan bleaching. Kedua tahapan ini diperlukan untuk menghilangkan lignin pada serat, karena lignin dapat menyebabkan kekakuan pada bahan alam (Pratiwi dkk, 2016). Selain itu, lignin akan menyebabkan warna pada serat selulosa menjadi lebih gelap dan selulosa asetat yang dihasilkan nantinya menjadi tidak murni. Pada penelitian ini, treatment ekstraksi dilakukan dengan menggunakan $\mathrm{NaOH}$ dan $\mathrm{H}_{2} \mathrm{O}_{2}$ dengan pertimbangan bahwa bahan ini low cost dan sedikit menimbulkan pencemaran lingkungan dibandingkan bahan kimia lainnya (Herawan dan Rivani, 2010). Sementara untuk treatment mekanis dapat dilakukan melalui metode bleaching dan ultrasonikasi. Kedua metode ini dapat menurunkan ukuran serat selulosa menjadi berukuran nano (Li et al, 2012). Li, et al (2012) berhasil membuat nanoselulosa berukuran $50-250 \times 10-20 \mathrm{~nm}$ menggunakan metode mekanis dengan ultrasonikasi. Selain kelebihan tersebut, pertimbangan penggunaan kedua metode ini karena prosesnya lebih mudah sehingga lebih efisien dalam proses ekstraksi, hemat dalam konsumsi energi dan biaya ekstraksi secara keseluruhan.

Sebenarnya untuk mendapatkan selulosa murni, cukup melalui treatment delignifikasi dan bleaching, tergantung pada aplikasinya. Namun untuk menghasilkan bioplastik yang memiliki sifat mekanis mendekati plastik sintetis, perlu dilakukan treatment pengecilan ukuran. Oleh karena itu, treatment mekanis seperti blending dan ultrasonikasi menjadi hal penting. Dalam upaya pencapaian sifat mekanis bioplastik tersebut, maka pada penelitian ini dilakukan langkah awal dengan tujuan untuk mengetahui pengaruh proses blending dan ultrasonikasi terhadap sifat morfologi serat limbah BKS sebelum diolah lebih lanjut menjadi selulosa asetat. Tujuan pengecilan ukuran selulosa melalui kedua proses ini ialah untuk mempermudah proses asetilasi yang berguna untuk menghasilkan selulosa asetat, karena selama ini yang menjadi problem dalam proses asetilasi adalah ketidakefisienan dari segi waktu. Diharapkan melalui penelitian ini, akan didapatkan nanoselulosa, agar waktu reaksi asetilasi pada tahap lanjutan pembuatan selulosa asetat tidak terlalu lama. Pengecilan ukuran partikel pada persiapan bahan untuk suatu proses, akan dapat memperluas permukaan kontak, sehingga luas permukaan semakin besar dan reaksi menjadi lebih cepat (Sulistyawati, 2008). Untuk dapat memastikan bahwa setelah proses ekstraksi, blending dan ultrasonikasi telah dihasilkan serat nanoselulosa, maka perlu dilakukan berbagai uji, antara lain uji gugus fungsi dengan Fourier Transformed Infra Red (FTIR), uji derajat kristalin dengan $X$-Ray Diffraction (XRD) dan uji penampakan permukaan serat dan ukurannya dengan Scanning Electron Mi- croscope (SEM). Ketiga uji ini merupakan uji struktur dan morfologi serat yang dapat digunakan untuk menganalisa perbedaan dan pengaruh blending dan ultrasonikasi pada serat limbah BKS sebelum maupun setelah treatment. Struktur kristalin dan morfologi akan berpengaruh pada ikatan antar atom penyusun suatu bahan, yang nantinya akan mempengaruhi sifat mekanis (kekuatan tarik, sifat kekerasan, kekuatan tekan dan sebagainya) dari suatu produk. Semakin kecil ukuran partikel dari suatu bahan, maka kerapatan atom semakin tinggi, ikatan antar atom semakin kuat dan sifat mekanis akan menjadi baik. Terlebih lagi bila partikel material yang dihasilkan berukuran nano (dalam hal ini nanoselulosa). Partikel nanoselulosa memiliki peningkatan dalam hal derajat kristalinitas, luas permukaan, dispersi dan sifat biodegradasi (Triapriani, 2016).

\section{METODE PENELITIAN}

Penelitian dilaksanakan di Laboratorium Teknologi Pengolahan (laboratorium Hasil Samping, Laboratorium Proses dan Laboratorium Kimia Politeknik LPP). Sementara analisis FTIR, XRD dan SEM dilakukan masing-masing di Laboratorium Fakultas MIPA UGM, Laboratorium Terpadu FMIPA UNY, dan LPPT UGM. Batang Kelapa Sawit (BKS) diperoleh dari kebun sawit milik Balai Latihan Kerja (BLK) LPP Rangkasbitung.

\section{Persiapan Bahan Baku Batang Kelapa Sawit (BKS)}

Batang kayu kelapa sawit dari hasil penebangan untuk replanting dipotong menjadi beberapa bagian yang dikenal dengan log. Log disimpan sekitar 1 bulan sebelum diolah supaya seratnya lebih lunak. Kemudian log diserut dengan menggunakan alat ketam kayu dipotong kecil-kecil, dikeringkan dan dihaluskan (diperkecil lagi ukurannya dengan menggunakan grinder). Setelah itu dilakukan pengayakan dan dilanjutkan dengan pengujian kadar air. Target kadar air yang akan digunakan untuk ekstraksi selulosa sekitar 4-5\%.

\section{Isolasi Nanoselulosa}

Serat serutan BKS dicuci dengan air disertai pengadukan dan pemanasan pada suhu $80^{\circ} \mathrm{C}$ selama 1 jam, lalu dicuci dengan air dingin. Setelah itu, serat BKS didelignifikasi dengan Natrium hidroksida $(\mathrm{NaOH}) 5 \%$ pada suhu yang sama disertai pengadukan dengan kecepatan putar $250 \mathrm{rpm}$ selama 3 jam untuk menghilangkan hemiselulosa dan lignin yang terdapat pada serat. Sebelum ke tahap bleaching, dilakukan pengkondisian basa pada larutan Hidrogen Peroxide $\left(\mathrm{H}_{2} \mathrm{O}_{2}\right) 5 \%$ melalui penambahahan larutan $\mathrm{NaOH}$ sedikit demi sedikit hingga pH 11 tercapai. Setelah larutan $\mathrm{H}_{2} \mathrm{O}_{2}$ siap, 
serat kemudian direndam dan diaduk dengan kecepatan yang sama selama 2 jam sambil dipanasi dengan suhu $80^{\circ} \mathrm{C}$ agar benar-benar menghilangkan lignin yang terdapat pada serat batang sawit. Setiap selesai tahapan perlakuan, serat dicuci dengan air mengalir sampai $\mathrm{pH}$ menjadi netral $(\mathrm{pH}$ 7). Perlakuan mekanik dilakukan dengan menggunakan blender rumah tangga (household blender) PHILIPS HR2096 pada 21.000 rpm. Larutan suspensi dengan kadar suspensi $0,4 \%$ berat pulp serat batang sawit diblend selama 10 menit. Lalu dilanjutkan ke tahapan ultrasonikasi dengan menggunakan alat ultrasonic cell crusher dengan waktu yang sama seperti proses blending, yaitu 10 menit. Nanoselulosa dengan tingkat kekeringan sekitar 3\% diperoleh dengan penyaringan suspensi serat selulosa batang sawit tua dengan menggunakan vacuum filter dan kemudian dilakukan pengeringan pada suhu $70^{\circ} \mathrm{C}$ semalam menggunakan oven listrik. Untuk memastikan hasil serat nanoselulosa, maka akan dilakukan analisis gugus fungsi dengan FTIR, analisis struktur kristalin dengan XRD dan analisis karakteristik morfologi menggunakan SEM pada sampel nanoselulosa kering.

\section{HASIL DAN PEMBAHASAN}

Proses blending dan sonikasi ditujukan untuk mengubah ukuran dan sifat morfologi pada selulosa limbah batang kelapa sawit yang dihasilkan setelah melalui proses ekstraksi. Ekstraksi dilakukan untuk mendapatkan serat nanoselulosa dengan kandungan $\alpha$-selulosa yang tinggi, sehingga akan mempermudah proses asetilasi sekaligus memperkuat sifat mekanis dari bioplastik dengan bahan baku selulosa asetat yang ingin dihasilkan di jangka panjang. Meskipun untuk mencapai bioplastik membutuhkan tahapan-tahapan lagi seperti asetilasi dan pelarutan/pencetakan, namun proses isolasi selulosa menjadi faktor penting yang menentukan keberhasilan tahapan proses selanjutnya. Bila terjadi kegagalan pada proses ekstrak-

\section{Alur Penelitian:}

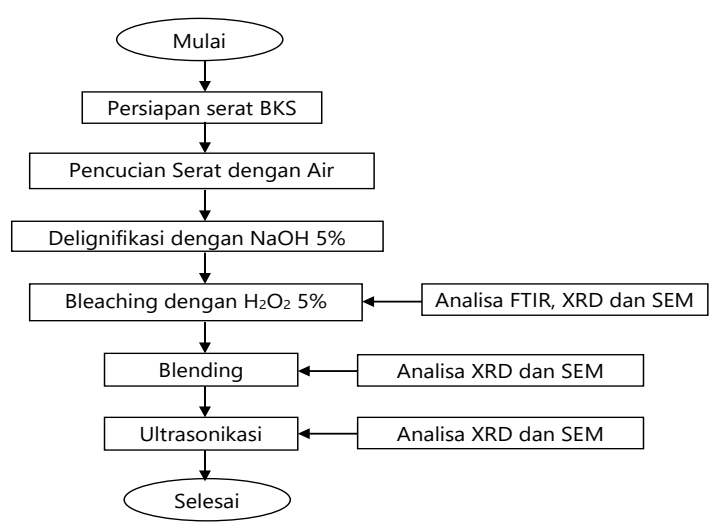

Gambar 1. Alur penelitian si, maka akan berakibat pada waktu asetilasi yang cenderung lama dan terbentuknya bioplastik yang yang mempunyai sifat mekanis yang kurang baik.

\section{Ekstraksi Selulosa dari Limbah BKS}

Selulosa pada penelitian ini diekstrak melalui tahap delignifikasi yang dilanjutkan dengan bleaching. Delignifikasi merupakan proses yang bertujuan untuk menghilangkan komponen selain selulosa pada serat limbah batang kelapa sawit dengan perlakuan alkali. Jenis larutan alkali yang digunakan ialah larutan $\mathrm{NaOH}$. $\mathrm{NaOH}$ dipilih karena dapat merusak struktur kristalin lignin dan struktur amorf hemiselulosa sehingga kedua senyawa ini dapat dipisahkan dari ikatan panjang rantai karbon yang terkandung dalam serat (Husni, 2018). Selama perlakuan alkali, kation $\mathrm{Na}^{+}$dapat memasuki pori terkecil selulosa dan mempermudah terjadinya reaksi pemutusan ikatan antar senyawa-senyawa dalam serat BKS. Polisakarida yang memiliki ikatan $B-1,4$ glikosida beserta hemiselulosa akan terdegradasi melalui mekanisme pemutusan ikatan pada ujungujung rantai karbonnya dan pada akhirnya hanya tersisa berupa rantai $\alpha$-selulosa (Clayden et al, 2012). Setelah tahap delignifikasi, selulosa disaring dan dibilas, hingga menghasilkan serat berwarna cokelat. Warna cokelat ini mengindikasikan masih ada sisa lignin yang terikut dalam selulosa.'

Untuk menghilangkan sisa lignin pada serat selulosa setelah delignifikasi, maka dilakukan proses pemutihan (bleaching) dengan bantuan $\mathrm{H}_{2} \mathrm{O}_{2}$. Pemilihan larutan $\mathrm{H}_{2} \mathrm{O}_{2}$ karena larutan ini bila di dalam larutan akan terurai menjadi $\mathrm{H}_{2} \mathrm{O}$ dan gas $\mathrm{O}_{2^{\prime}}$ gas $\mathrm{O}_{2}$ sangat efisien dalam proses bleaching, karena low cost, mampu memisahkan banyak lignin dengan cukup baik dan hanya sedikit menimbulkan pencemaran lingkungan. Konsentrasi $\mathrm{H}_{2} \mathrm{O}_{2}$ yang digunakan pada penelitian ini yaitu sebesar $5 \%$. Ini mengacu pada penelitian sebelumnya Sukmawan dkk (2018) bahwa proses bleaching dengan bantuan larutan $\mathrm{H}_{2} \mathrm{O}_{2}$ dapat optimal memisahkan lignin pada konsentrasi $5 \%$, selain itu juga dapat menghasilkan selulosa dengan struktur kristalin yang cukup tinggi. Setelah selesai bleaching, didapatkan selulosa BKS yang berwarna lebih terang dari sebelumnya (kekuningan). Warna terang ini menunjukkan bahwa pigmen serta lignin sudah larut sehingga didapatkan selulosa dengan kemurnian tinggi dengan tingkat kecerahan yang tinggi pula. Selulosa yang didapatkan dari proses ini, kemudian dicuci bersih berulang-ulang hingga mencapai pH netral.

\section{Treatment Mekanis pada Selulosa BKS.}

Poses blending dilakukan dengan kecepatan putar 21.000 rpm selama 10 menit. Proses ini bertujuan untuk mendapatkan serat selulosa yang lebih halus 
dengan harapan dapat mengubah selulosa yang berukuran mikro menjadi berukuran nano. Proses blending dapat dilakukan dengan menggunakan blender rumah tangga sebagaimana yang pernah diteliti oleh Uetani dkk (2011) dan Nakagaito dkk (2015). Proses mekanis ini lebih terjangkau. Meskipun konsep ini bukan hal yang baru, namun paten terkait penggunaan blender untuk memperoleh serat plastik sudah pernah diteliti pada tahun 1989 oleh Galati. Namun Uetani telah menjadi orang pertama yang menggunakan blender rumah tangga (household blender) untuk memperoleh serat selulosa. Penelitian-penelitian tersebut menjadi referensi di penelitian ini, yang juga mencoba mendapatkan serat selulosa berukuran nano dari BKS menggunakan blender rumah tangga. Diharapkan dari proses ini diperoleh serat nanoselulosa dalam jumlah banyak dengan harga yang relatif murah karena efisien dari segi biaya dan energi.

Tahapan akhir dalam upaya perolehan serat nanoselulosa dari BKS ialah dengan metode ultrasonikasi. Metode ini bertujuan untuk menurunkan ukuran nanoselulosa dengan bantuan gelombang ultrasonik. Pada penelitian ini, proses ultrasonikasi dilakukan selama 10 menit dengan harapan dapat memecah struktur amorf dari selulosa sehingga dihasilkan jumlah nanoselulosa yang lebih banyak dengan ukuran partikel yang lebih kecil. Target capaian ialah struktur kristalin dan penurunan struktur amorf yang ada di serat BKS. Perubahan struktur kristalin serta sifat morfologi serat sebelum dan setelah proses blending dan ultrasonikasi akan diperlihatkan pada hasil XRD dan SEM.

\section{Analisa FTIR}

Analisa FTIR ditujukan untuk mengetahui perubahan gugus fungsi yang terjadi pada serat selulosa sebelum treatment dan setelah treatment ekstraksi (dalam hal ini setelah bleaching), blending

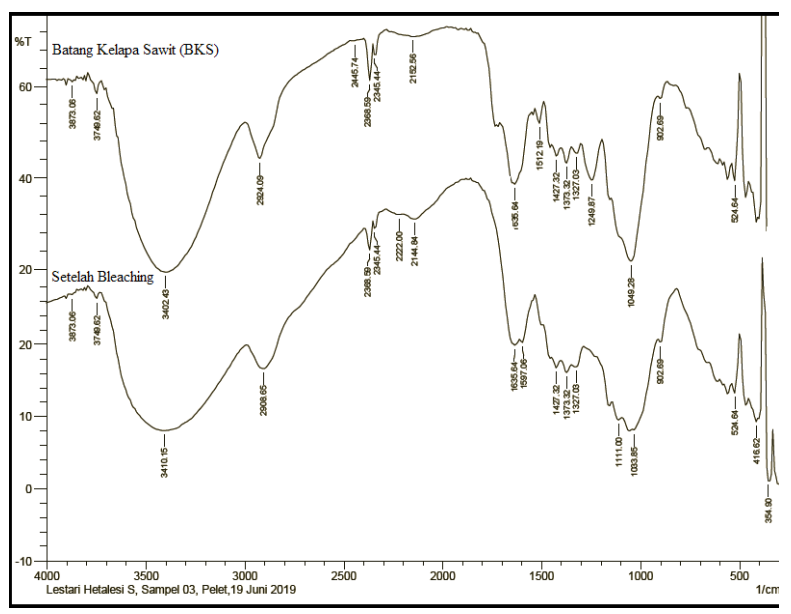

Gambar 2. Hasil analisa FTIR serat BKS dan sampel BKS setelah bleaching dan ultrasonikasi. Hasil uji FTIR dianalisa dengan menginterpretasikan puncak-puncak serapan dari spektrum inframerah. Pada gambar 2 nampak hasil analisa FTIR sampel BKS sebelum dan setelah ekstraksi.

Spektrum IR selulosa terdapat pada gugus fungsi utama O-H dengan daerah serapan 3400-3500 $\mathrm{cm}^{-1}, \mathrm{C}-\mathrm{H}$ dengan daerah serapan $2800-2900 \mathrm{~cm}^{-1}$, C-O stretching dengan daerah serapan 1035-1060 $\mathrm{cm}^{-1}$ dan C-O glikosida dengan puncak $1111 \mathrm{~cm}^{-1}$ yang merupakan ciri khas dari senyawa ini. Kamal et al (2014) mengatakan bahwa karakterisasi ikatan selulosa pada spektra serapan di bilangan gelombang 3400-3500 $\mathrm{cm}^{-1}$ merupakan corresponding stretching gugus $\mathrm{O}-\mathrm{H}$. Selain puncak-puncak tersebut, selulosa pada daerah fingerprint dapat memberikan puncak di sekitar $1300 \mathrm{~cm}^{-1}$ yang mengindikasikan adanya $\mathrm{C}-\mathrm{H}$ bending dan di sekitar $1400 \mathrm{~cm}^{-1}$ yang mengindikasikan adanya $\mathrm{CH}_{2}$ bending (Marchessault dan Sundararajan, 1983).

Grafik di atas memperlihatkan adanya perbedaan antara spektra IR sebelum dan setelah treatment ekstraksi. Pada spektra IR sebelum treatment di atas, menunjukkan adanya ikatan $\mathrm{C}=\mathrm{O}$ ester pada bilangan gelombang sekitar $1740 \mathrm{~cm}^{-1}$ dan $\mathrm{C}=\mathrm{C}$ cincin aromatik pada bilangan gelombang $1512,19 \mathrm{~cm}^{-1}$ yang masing-masing merupakan ciri khas ikatan hemiselulosa dan lignin. Semua tanaman berkayu memiliki hemiselulosa dan lignin (Zain dkk, 2014). Sementara pada spektra sampel setelah bleaching, puncak ester hemiselulosa menghilang dan puncak cincin aromatik lignin melemah. Lemahnya kedua puncak tersebut mengindikasikan bahwa hemiselulosa dan lignin semakin berkurang atau bahkan hilang setelah proses bleaching dengan $\mathrm{H}_{2} \mathrm{O}_{2} 5 \%$. Ini juga sesuai dengan teori yang dikemukakan oleh Abraham et al (2011) serta Sundari dan Atmakuru (2012) yang menyatakan bahwa bila pada spektra FTIR tidak menunjukkan puncak (bilangan gelombang) $\mathrm{C}=\mathrm{O}$ ester pada $1720 \mathrm{~cm}^{-1}$ dan $C=C$ cincin aromatik pada $1512 \mathrm{~cm}^{-1}$, maka ini membuktikan bahwa lignin dan hemiselulosa telah terpisah dari selulosa setelah proses bleaching. Selain itu, bukti telah terbentuknya selulosa murni setelah treatment $\mathrm{H}_{2} \mathrm{O}_{2}$ juga diperlihatkan pada puncak $1111 \mathrm{~cm}^{-1}$ yang sebelumnya puncak ini tidak ada pada serat BKS sebelum ekstraksi. Ciri khas lainnya dari senyawa selulosa yang terbentuk dari serat limbah BKS diperlihatkan pada Tabel 1.

Pada Tabel 1 terlihat gugus fungsi pada masing-masing bilangan gelombang penyusun struktur kimia selulosa. Hasil spekrum IR selulosa BKS menunjukkan adanya puncak $3410,15 \mathrm{~cm}^{-1} ; 2908,65$ $\mathrm{cm}^{-1} ; 1427,32 \mathrm{~cm}^{-1} ; 1327,03 \mathrm{~cm}^{-1}$ dan $1033,85 \mathrm{~cm}^{-1}$. 
Tabel 1. Bilangan gelombang $\left(\mathrm{cm}^{-1}\right)$ selulosa

\begin{tabular}{clccc}
\hline & & \multicolumn{3}{c}{ Bilangan Gelombang $\left.\mathbf{( c m}^{-1}\right)$} \\
\cline { 3 - 5 } No & Gugus Fungsi & $\begin{array}{c}\text { Selulosa } \\
\text { murni }\end{array}$ & $\begin{array}{c}\text { Selulosa } \\
\text { Hasil } \\
\text { Penelitian }\end{array}$ & $\begin{array}{c}\text { Selulosa } \\
\text { (Husni \& } \\
\text { Ruslan, } \\
\text { 2018) }\end{array}$ \\
\hline 1 & O-H stretch & 3350 & 3410,15 & 3423 \\
2 & C-H stretch & 2800 & 2908,65 & 2854 \\
3 & $\mathrm{CH}_{2}$ bend & 1400 & 1427,32 & 1431 \\
4 & CH bend & 1300 & 1327,03 & 1323 \\
5 & C-O stretch & 1035 & 1033,85 & 1020 \\
\hline
\end{tabular}

Hasil ini memiliki kemiripan spektra IR dengan selulosa murni dan dengan selulosa hasil penelitian Husni dan Ruslan (2018), sehingga dapat disimpulkan bahwa proses ekstraksi telah dapat memisahkan lignin dan hemiselulosa dari selulosa dan kemungkinan struktur nanoselulosa telah mulai terbentuk. Akan tetapi, jumlah nanoselulosa ini masih sedikit sehingga perlu ditingkatkan jumlahnya melalui treatment mekanis, seperti dengan proses blending dan ultrasonikasi.

Untuk lebih jelasnya penurunan serapan bilangan gelombang khas milik selulosa BKS ditunjukkan pada gambar di bawah ini: Pada grafik di atas terlihat bahwa terjadi penurunan indeks pada gugus fungsi penyusun senyawa yang terdapat pada serat BKS. Penurunan indeks terjadi pada hampir semua gugus dan ini memperkuat dugaan bahwa hemiselulosa dan lignin telah terpisah dari rantai selulosa, karena sebenarnya beberapa gugus fungsi tersebut juga dimiliki oleh ketiga senyawa. Dengan penurunan indeks berarti telah terjadi pengurangan senyawa organik yang terdapat pada serat BKS. Pembeda gugus utama selulosa dengan lignin dan hemiselulosa terdapat pada gugus C-O glikosida. Selain itu juga pada gugus O-H di spektra BKS dan sampel setelah bleaching mengalami pergeseran puncak dari bilangan gelombang $3402 \mathrm{~cm}^{-1} \mathrm{ke} 3410,15 \mathrm{~cm}^{-1}$. Ini menunjukkan bahwa struktur kimia serat telah beralih ke

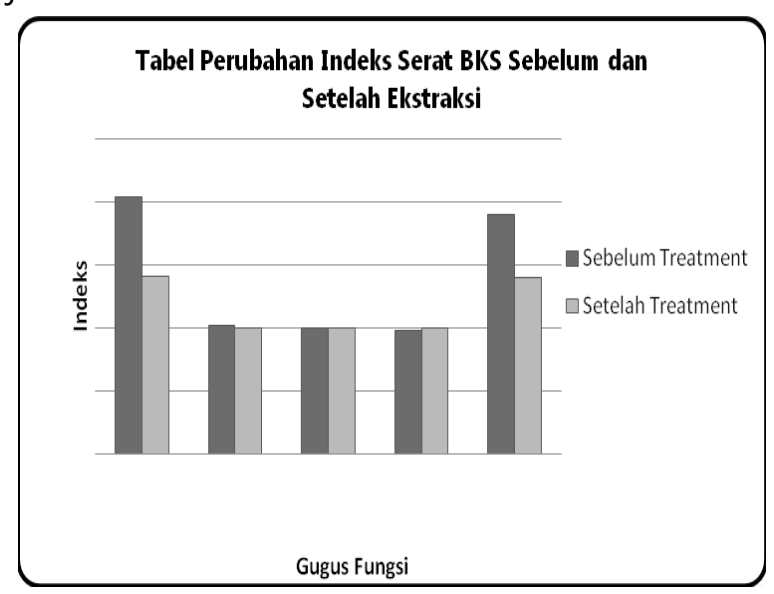

Gambar 3. Perubahan indeks serat bks sebelum dan setelah ekstraksi struktur selulosa murni dengan kandungan indeks $\mathrm{O}-\mathrm{H}$ selulosa murni tanpa kandungan $\mathrm{O}-\mathrm{H}$ dari lignin dan hemiselulosa. Nilai indeks ini dapat dilihat pada Gambar 3.

\section{Analisa XRD}

Pengujian XRD menggunakan mesin model Rigaku Miniflex 600. Pada kondisi temperatur kamar degan radiasi $\mathrm{Cu} \mathrm{K} \alpha(0,154 \mathrm{~nm}, 40 \mathrm{kV}$ dan $15 \mathrm{mAA})$. Intensitas radiasi $\mathrm{Cu} \mathrm{K} \alpha$ direkam pada sudut $2 \theta$ dalam rentang sudut $0^{\circ}$ sampai $40^{\circ}$ dengan pertambahan $0,02^{\circ}$ tiap langkah dan kecepatan scanning $10 \%$ min. Derajat kristalisasi (\%Cr) dari struktur selulosa dihitung berdasarkan perbandingan luasan area (Poletto et al, 2014), yaitu:

$$
\begin{aligned}
& \% C r=\frac{A(C r)}{A(C r)+A(\mathrm{am})} \times 100 \% \\
& \% C r=\frac{A(\mathrm{Cr})}{A(\mathrm{Cr})+A(\mathrm{am})} \times 100 \%
\end{aligned}
$$

Keterangan: A (cr) adalah luasan atau areal di bawah puncak yang sesuai bidang sampel dengan nilai indeks Miller ( $\left.\begin{array}{lll}1 & 0 & 1\end{array}\right)$ dan ( $\left.\begin{array}{lll}0 & 0 & 2\end{array}\right)$ pada sudut $2 \theta$ dalam kisaran $14,5^{\circ}$ dan $22,2^{\circ}$ secara berurutan yang mewakili bahan kristal dan A (am) adalah luasan atau areal selain I (cr).

Grafik hasil XRD pada sampel BKS sebelum treatment dan setelah treatment melalui proses bleaching, blending dan ultrasonikasi ditunjukkan pada gambar 4 berikut.

Gambar 4 menunjukkan X-ray difraktogram dari non perlakuan kimia, perlakuan $\mathrm{NaOH}$ diikuti $\mathrm{H}_{2} \mathrm{O}_{2}$ pada kondisi basa ( $\mathrm{pH}$ 11), perlakuan blending dan perlakuan ultasonikasi dengan bantuan alat sonikator pada serat BKS. Sampel-sampel tersebut menunjukkan puncak pada sudut $2 \theta=14,5^{\circ}$ yang sesuai dengan indeks Miller bidang kristal ( $\left.\begin{array}{lll}1 & 1 & 0\end{array}\right)$ dan $22,2^{\circ}$ yang bersesuaian dengan bidang kristal (2 2 0). Kedua puncak tersebut merupakan bidang Kristal dari celulosa I (Sukmawan dkk, 2018). Dengan menghitung luas area di bawah puncak kristal, derajat kristalisasi dari serat BKS sebelum per-

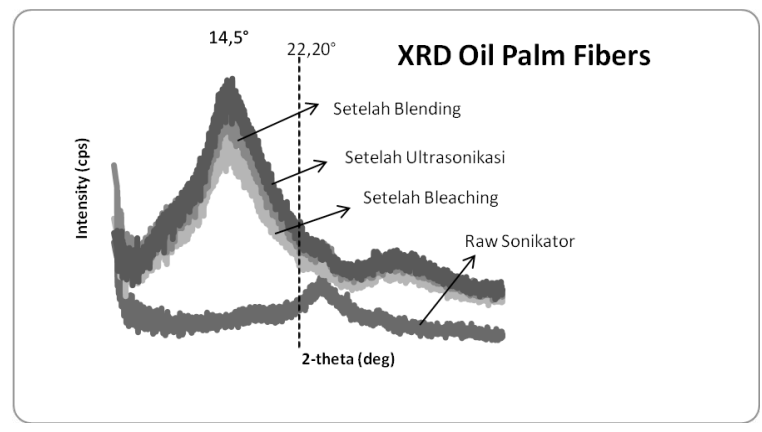

Gambar 4. X-ray difraktogram serat selulosa dari batang kelapa sawit (bks) sebelum dan sesudah mengalami perlakuan kimia dan mekanik 
lakuan kimia dengan diameter serat sekitar $10 \mu$. Derajat kristalisasi serat BKS sebelum mengalami perlakuan kimia maupun mekanik adalah $8 \%$ dan meningkat signifikan menjadi $25,8 \%$ sesudah mengalami perlakuan kimia dengan $\mathrm{NaOH}$ dan diikuti oleh bleaching $\left(\mathrm{H}_{2} \mathrm{O}_{2}\right)$. Hal ini menunjukkan efektifitas dari perlakuan $\mathrm{NaOH}$ yang menghilangkan hemiselulosa dan sebagian lignin yang kemudian diikuti perlakuan $\mathrm{H}_{2} \mathrm{O}_{2}$ yang menghilangkan keseluruhan lignin yang merupakan bagian non kristal (amophose). Perlakuan blending menyebabkan sedikit penurunan derajat kristalisasi menjadi $21,09 \%$. Hal ini dimungkinkan karena proses blending memisahkan sebagian serat-serat yang berukuran besar $(9-10 \mu)$ sesudah mengalami perlakuan kimia menjadi serat yang lebih kecil be-

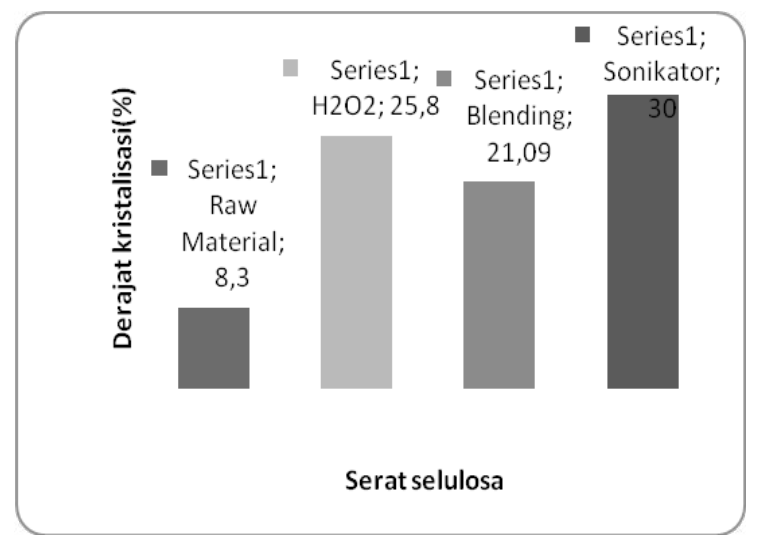

Gambar 5. Derajat kristalisasi serat sebelum (raw material) dan sesudah mengalami perlakuan kimia dan mekanis.
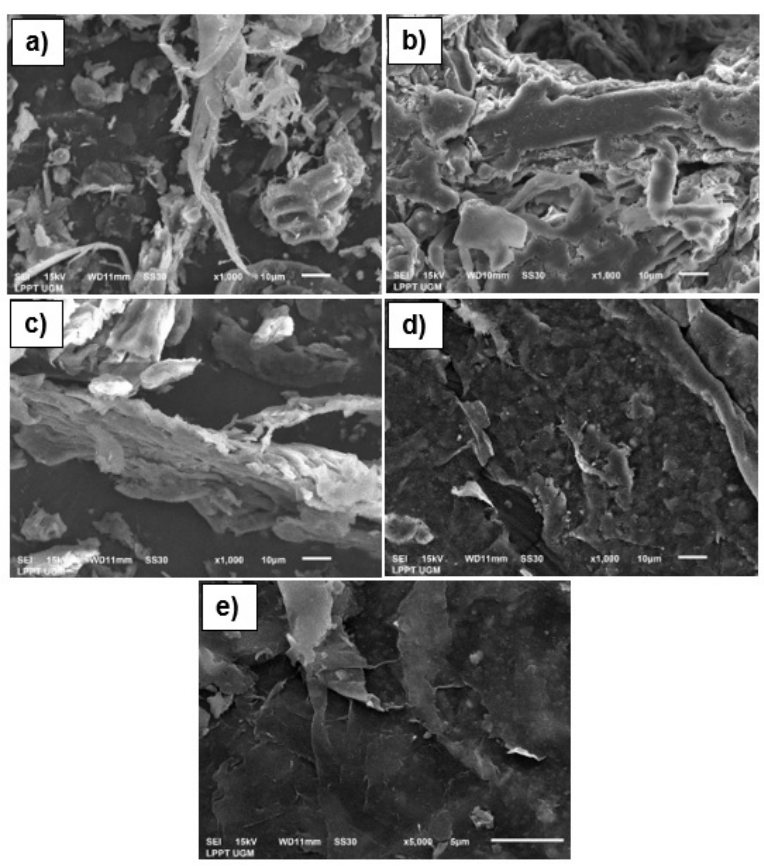

Gambar 6. Hasil analisis SEM a) serat BKS (raw material); b) perlakuan $\mathrm{H}_{2} \mathrm{O}_{2}$; c) perlakuan Blending; d) perlakuan sonikator (SEM, skala 10 $\mu \mathrm{m}$ ); dan e) perlakuan sonikator (SEM, skala $5 \mu \mathrm{m}$ ). rukuran $5 \mu$. Ada sebagian serat yang mengalami kerusakan akibat benturan dengan pisau blender saat proses blending yang mungkin berpengaruh secara internal pada transisi struktur kristal pada serat menjadi amorphose yang berpengaruh penurunan derajat kristalisasi. Sementara proses sonikator efektif memperkecil sebagian ukuran serat selulosa menjadi $2-3 \mu$ dan mengurangi bagian amorphose dan mensisakan bagian struktur kristal yang lebih banyak dibandingkan tahapan proses sebelumnya. Hasil perhitungan derajat kristalin diperlihatkan pada Gambar 5.

\section{Analisis SEM}

Hasil analisa SEM pada serat BKS sebelum dan setelah perlakuan kimia dan mekanis ditunjukkan pada Gambar 6.

Struktur morfologi selulosa dari BKS sebelum dan setelah perlakuan kimia serta mekanis terlihat berbeda pada gambar di atas. Pada sampel BKS tanpa perlakuan, struktur permukaan serat masih bercampur antara bagian amorf dan kristalin. Namun setelah perlakuan kimia dengan $\mathrm{H}_{2} \mathrm{O}_{2}$ (Gambar 6b), permukaan serat sudah mulai teratur namun terlihat masih ada bagian serat yang tidak teratur, ini mengindikasikan bahwa bagian amorf dari serat masih cukup banyak. Setelah perlakuan mekanis dengan proses blending (Gambar 6c), permukaan selulosa terlihat lebih teratur, terpotong menjadi serat yang lebih pendek, namun ada beberapa bagian yang rusak pada permukaan yang teratur (struktur kristalin). Beda lagi dengan struktur permukaan serat setelah ultrasonikasi dengan sonikator yang ditunjukkan pada Gambar $6 \mathrm{~d}$ dan $6 \mathrm{e}$. Pada serat hasil ultrasonikasi, permukaan serat selulosa terlihat jauh lebih teratur dibandingkan sebelumnya, apalagi pada skala $5 \mu \mathrm{m}$. Hal ini menunjukkan bahwa proses ultrasonikasi lebih baik dalam menghasilkan serat nanoselulosa dengan ukuran serat yang lebih kecil dan struktur kristalin yang lebih banyak. Ini juga didukung dari hasil derajat kristalin dari hasil analisa XRD yang mencapai $30 \%$. Proses ultrasonikasi dapat memperbaiki struktur kristalin dari serat hasil proses blending yang sebelumnya derajat kristalinnya menurun hingga $21,09 \%$.

\section{KESIMPULAN DAN SARAN}

Perlakuan kimia dan mekanis dapat mengubah struktur selulosa menjadi nanoselulosa dengan derajat kristalin tertentu. Pada hasil didapatkan bahwa terjadi perubahan struktur kimia maupun morfologi pada serat BKS setelah bleaching, blending dan ultrasonikasi. Serat BKS mengalami penurunan derajat kristalin setelah proses blending, namun mengalami peningkatan kembali seki- 
tar 9\% setelah proses ultrasonikasi. Hasil SEM menunjukkan bahwa permukaan serat menjadi lebih teratur setelah proses ultrasonikasi dibandingkan setelah proses blending. Untuk peneliti selanjutnya, bila ingin menghasilkan nanoselulosa dalam jumlah optimal, maka perlu diteliti lebih lanjut mengenai variasi kecepatan putar pada proses blending, sehingga tidak ada serat selulosa yang rusak setelah struktur kristalin terbentuk.

\section{DAFTAR PUSTAKA}

Abraham, E., Deepa, B. L. A., Jacob, M., Thomas, S. Cvelbar, U., et al. (2011). Extraction of nanocellulose fibrils from lignocellulosic fibres: a novel approach. Carbohydrate Polimers, 86, 1468-1475.

Agro. (2017). 1,5 Juta Ha Kebun Petani Sawit Wajib Direplanting. Agrofarm.

Direktorat Jenderal Perkebunan, Statistik Perkebunan Indonesia 2015-2017 Kelapa Sawit.

Clayden, J., Greeves, N., \& Warren, S. (2012). Organic chemistry. Oxford University Press.

Galati, C. C., 1989, Motion Control Industries, Inc. US Patent 4,811,908.

Gemili, S., Yemeniciog, A., \& Altinkaya, S. A. (2010). Development of antioxidant food packaging materials with controlled release properties. J. of Food Engineering, 96, 325332. doi:10.1016/j.jfoodeng.2009.08.020

Herawan, T., \& Rivani, M. (2010). Produksi Aseton-Butanol-Etanol dari Hidrolisat Tandan Kosong Kelapa Sawit. Laporan Pnelitian Kerjasama PPKS-PTPN IV, 16.

Husni, D. A. P., Rahim, E. A., Rusian. (2018). Pembuatan membran selulosa asetat dari selulosa pelepah pohon pisang. Kovalen, 4(1), 41-52.

Kamal, A. H., F. M., Abd-Elrahim B., Lotfy S. (2014). Characterization and Some Properties Of Cellulose Acetate-Co-Polyethylene Oxide Blends prepared by the use of gamma irradiation. Journal of Radiation Research and Applied Sciences. 7, 146-153.

Li, J., Wei, X., Wang, Q. (2012). Homogeneous isolation of nanocellulose from sugarcare bagasse by high pressure homogenization. Carbohydrate Polmers, 90(4), 1069-1613.

Li, W., Yue, J., Liu, S. (2012). Preparation of nanocrystalline cellulose via ultrasound and its reinforcement capability for poly(vinyl alcohol) composites. Ultrasonics Sonochemistr, 19, 479-485.
Marchessault, R. H., P. R. Sundarajan. (1983). Cellulose in : Aspinal, G. O. (editor) the polysacaride. London: Academic Press, Inc.

Moore A. (2013). Draft: Trap development experiment. Research in support of the Guam coconut rhinoceros beetle eradication project. Cooperative extension service, University of Guam.

Nakagaito, A. N., Ikenaga, K., dan Takagi, H. Cellulose nanofiber extraction from grass by $a$ modified kitchen blender. Mod. Phys. Lett. B, 29, 06-07.

Pratiwi, R., Rhayu, D., Barliana, M. I. (2016). Pemanfaatan Selulosa dari Limbah Jerami Padi (Oryza sativa) sebagai Bahan Bioplastik, 3(3).

Robertson, R. M., Thomas, W. C., Suthar, J. N., \& Brown, D. M. (2012). Accelerated degradation of cellulose acetate cigarette filters using controlled-release acid catalysis. Green Chemistry, 14(8), 22662272.

Sukmawan R, Saputri L. H, Rochmadi, Rochardjo H. S. B. (2019). The effects of the blending condition on the morphology, crystallinity, and thermal stability of cellulose microfibers obtained from bagasse. Indonesian Journal of Chemistry, 19 (1), 165-175.

Sundari, M.T., Atmakuru, R. (2012). Isolation and characterization of cellulose nanofibers from the aquatic weed watwer hyacinth: Eichhornia crassipers. Carbohydrate polimers, 87

(2). DOI:10.1016/j.carbpol.2011.09.076.

Triapriani. (2016). Pembuatan Nanoselulosa Dari Tandan Kosong Sawit Dengan Metode Hidrolisis Asam. Fakultas Matematika dan Ilmu Pengetahuan Alam Universitas Lampung : Bandar Lampung.

Poletto, M., Júnior, H. L. O., and Zattera, A. J. (2014). Native cellulose: Structure, characterization and thermal properties. Materials, 7 (9), 6105-6119. https://doi.org/10.3390/ ma7096105.

Uetani, K. dan Yano, H. (2011). Nanofibrillation of wood pulp using a high-speed blender, Biomacromolecules, 12 (2), 348-353, Feb 2011.

Zain, N. F. M., Yusop, S. M., and Ahmad, I. 2014. Preparation and karacterization of cellulose and nanocellulose from pamelo (Citrus grandis) Albedo. Jornal of Nuttrition and Food Sciences, 5(1), 1-4. 